\title{
亮点
}

\section{太阳耀斑区等离子体加热的一种新方式——“蜊蚪 撞日”}

\author{
李乐平 ${ }^{1,2 *}$
}

1. 中国科学院国家天文台太阳活动重点实验室, 北京 100101;

2. 中国科学院大学, 北京 100049

*联系人, E-mail: lepingli@nao.cas.cn

收稿日期: 2021-03-15; 接受日期: 2021-03-16; 网络出版日期: 2021-04-27

中国科学院战略性先导科技专项(编号：XDB41000000)、国家自然科学基金(编号：12073042)、中国科学院基础前沿科学研究计划(编号： ZDBS-LY-SLH013)和中国科学院前沿科学重点研究项目(编号: QYZDJ-SSW-SLH050)资助

摘要太阳耀斑是太阳大气中的磁能通过磁重联快速释放后产生的一种活动现象. 时至今日, 耀斑区内等离子体 的加热方式还有待厘清. 最近, 来自于乔治梅森大学和北京大学等高等院校和科研院所的研究人员发现耀斑过程 中产生的一群暗黑色“蝌蚪”状下落流陆续撞击耀斑环顶端, 并剧烈加热撞击处的日冕大气至一两千万摄氏度的 高温. 这一新发现也为太阳和恒星耀斑期间常见的准周期脉动现象提供了一种新解释.

关键词日冕，太阳耀斑，磁重联，等离子体加热

PACS: $96.60 . P-$, 96.60.qe, 96.60.Iv, 52.50.-b

太阳耀斑是太阳大气中一种剧烈爆发活动现象, 表现为各种波段电磁辐射的急剧增强，是造成灾害性 空间天气的主要源头之一. 它在短时间(几分钟到数小 时)内把日冕等离子体加热到几百万至几千万摄氏度, 并把电子和离子加速到极高的能量 ${ }^{[1]}$. 耀斑、日冕物 质抛射和暗条爆发等太阳剧烈爆发活动都与磁场演化 密切相关 ${ }^{[2,3]}$. 磁重联是描述磁场拓扑重构的一个基本 物理过程，它在吸积盘、伽马暴、磁星、日(恒星) 冕、地(行星)磁层和等离子体实验室等泛宇宙的磁化 等离子体系统中扮演着十分重要的角色. 人们通常认 为耀斑通过磁重联快速释放自由磁能，并把磁能转化
为热能和动能等其他形式的能量. 近 20 年来, 在太阳 (恒星)耀斑观测中，人们发现了大量的准周期电磁辐 射信号, 并称之为准周期脉动. 人们普遍认为这些准 周期脉动信号可能是由被调制的磁重联或者磁环的磁 流体振荡所产生的 ${ }^{[4,5]}$.

在耀斑演化过程中，明亮的耀斑环在重联点下方 形成，连接着上方的重联区和下方的耀斑带. 在耀斑 环上方，一个多热(约500万-1000万摄氏度)、弥散的 扇形区域出现．穿过此扇形区域，一群暗黑色“蝌蚪” 状磁结构向下朝向耀斑环快速游动 ${ }^{[6]}$. 这群小 “蝌蚪” 自发现以来就引起了大家的广泛关注。它们的初始高

引用格式: 李乐平. 太阳耀斑区等离子体加热的一种新方式——“蝌蚪撞日”. 中国科学: 物理学 力学 天文学, 2021, 51: 119631

Li L-P. Tadpole-like downflows: A new mechanism for plasma heating in the flaring solar corona (in Chinese). Sci Sin-Phys Mech Astron, 2021, 51: 119631, doi: 10.1360/SSPMA-2021-0053 
度(约 $80 \mathrm{Mm})$ 、寿命(约几分钟)、温度(约 1000 万摄氏 度)、密度(小于 $10^{9} \mathrm{~cm}^{-3}$ )、面积(约 $14 \mathrm{Mm}^{2}$ )、速度(约 $150 \mathrm{~km} / \mathrm{s}$ )、加速度(约- $420 \mathrm{~m} / \mathrm{s}^{2}$ ) 和形成机制等方方面 面都获得了全面系统的分析研究 ${ }^{[6-11]}$. 然而, 时至今日, 关于小“蝌蚪”的形成机制还存在较大争议. 不过, 人们 通常认为它们可能与耀斑过程中产生的重联出流相 关 $^{[7]}$, 或者与新形成后快速收缩的磁环相关 ${ }^{[8]}$. 由此可 见, 它们很可能蕴含着耀斑过程中能量释放的重要信 息 ${ }^{[12]}$, 但是人们对其涉及的具体物理过程仍缺乏认识. 过去, 人们几乎都是使用日面边缘处的耀斑观测 数据来研究这些小“蝌蚪”, ${ }^{[6-10]}$, 而在日面上极少寻受 到它们的踪迹. 在先前研究的这些边缘耀斑事件中, 小“蝌蚪”们在朝向太阳前进时, 还未抵达耀斑环顶便 停止了游动. 因此, 人们无法看到它们与耀斑环相撞 的景象. 2013年4月11日, 太阳动力学天文台(Solar Dynamic Observatory, SDO)卫星上搭载的太阳大气成像 仪(Atmospheric Imaging Assembly, AIA)在日面中心附 近区域捕捉到一个M6.5级耀斑. 最近, 乔治梅森大学 的博士后Tanmoy Samanta博士和北京大学的田晖教 授等人 ${ }^{[11]}$ 分析了这个耀斑事件. 得益于AIA对此事件
绝佳的观测视角，他们细致地研究了耀斑期间小“蝌 蚪”们在日面上的精细动力学过程, 获得了重要研究成 果. 他们发现一条条小“蝌蚪”撞击到耀斑环顶端, 致使 撞击处日冕等离子体的温度剧烈升高到 1000 万- 2000 万摄氏度，并伴有显著的极紫外和X射线波段辐射增 强. 由于耀斑期间不同“蝌蚪”撞击耀斑环顶的时间存 在差异, 日冕等离子体温度的升高和辐射的增强是间 歇性发生的, 导致全日面积分的X射线流量曲线呈现 出准周期性的变化. 这种准周期性变化与耀斑过程中 常见的准周期脉动完美吻合 ${ }^{[11]}$.

上述研究结果表明，小“蝌蚪”们陆续撞击耀斑环 顶端为耀斑期间的日冕等离子体加热做出了不可忽视 的贡献 ${ }^{[11]}$. 这一新发现也为解释太阳和恒星耀斑期间 多见的准周期脉动现象提供了一种新思路. 未来, 研 究者需要寻找更多位于日面上的耀斑事件, 通过统计 工作来研究它们演化过程中小“蝌蚪”与耀斑环之间的 相互作用，量化“蝌蚪撞日”对耀斑期间日冕等离子体 加热的贡献. 此外, 还需要使用磁流体力学数值模拟 的方法重现以上观测结果, 进一步探索耀斑期间“蝌蚪 撞日”加热日冕等离子体的具体物理机制.

\section{参考文献}

1 Fang C, Ding M D, Chen P F. Physics of Solar Active Regions (in Chinese). Nanjing: Nanjing University Press, 2008 [方成, 丁明德, 陈鹏飞. 太 阳活动区物理. 南京: 南京大学出版社, 2008]

2 Chen A Q, Wang J X. On the possibility of predicting flare index and CME velocity using vector magnetograms. Sci China-Phys Mech Astron, 2020, 63: 269512

3 Zhang H Q. From polarimetry to helicity: Studies of solar magnetic fields at the Huairou Solar Observing Station. Sci China-Phys Mech Astron, 2019, 62: 999601, arXiv: 1912.06557

4 Tian H, Young P R, Reeves K K, et al. Global sausage oscillation of solar flare loops detected by the Interface Region Imaging Spectrograph. Astrophys J, 2016, 823: L16, arXiv: 1605.01963

5 Li D, Zhang Q M. Quasi-periodic pulsations with multiple periods in hard X-ray emission. Mon Not R Astron Soc-Lett, 2017, 471: L6-L10, arXiv: 1706.01680

6 McKenzie D E, Hudson H S. X-ray observations of motions and structure above a solar flare arcade. Astrophys J, 1999, 519: L93-L96

7 Guo L J, Huang Y M, Bhattacharjee A, et al. Rayleigh-Taylor type instabilities in the reconnection exhaust jet as a mechanism for supra-arcade downflows in the Sun. Astrophys J, 2014, 796: L29, arXiv: 1406.3305

8 Savage S L, McKenzie D E, Reeves K K. Re-interpretation of supra-arcade downflows in solar flares. Astrophys J, 2012, 747: L40, arXiv: 1112.3088

9 Li L P, Zhang J, Su J T, et al. Oscillation of current sheets in the wake of a flux rope eruption observed by the Solar Dynamics Observatory. Astrophys J, 2016, 829: L33

10 Samanta T, Tian H, Nakariakov V M. Evidence for vortex shedding in the Sun's hot corona. Phys Rev Lett, 2019, 123: 035102, arXiv: 1907.08930

11 Samanta T, Tian H, Chen B, et al. Plasma heating induced by tadpole-like downflows in the flaring solar corona. Innovation, 2021, 2: 100083, 
12 Reeves K K, Török T, Mikić Z, et al. Exploring plasma heating in the current sheet region in a three-dimensional coronal mass ejection simulation. Astrophys J, 2019, 887: 103, arXiv: 1910.05386

\title{
Tadpole-like downflows: A new mechanism for plasma heating in the flaring solar corona
}

\author{
LI Le-Ping ${ }^{1,2 *}$ \\ ${ }^{1}$ CAS Key Laboratory of Solar Activity, National Astronomical Observatories, Chinese Academy of Sciences, Beijing 100101, China; \\ ${ }^{2}$ University of Chinese Academy of Sciences, Beijing 100049, China
}

Solar flares are a solar activity phenomenon powered by magnetic energy released rapidly through magnetic reconnection. So far the mechanisms for heating the flaring plasma are still under debate. Recently, the researchers from George Mason University, Peking University, etc. discovered that a group of dark tadpole-like downflows, produced during flares, collide with the apexes of flare loops, and strongly heat the surrounding plasma to a higher temperature of 10-20 MK. This discovery also provides a new and alternative explanation for the quasi-periodic pulsations that are often observed in solar and stellar flares.

solar corona, solar flares, magnetic reconnection, plasma heating

PACS: 96.60.P-, 96.60.qe, 96.60.Iv, 52.50.-b

doi: $10.1360 /$ SSPMA-2021-0053 